\title{
O USO DE PALEOSSOLOS E PERFÍS DE ALTERAÇÃO PARAA IDENTIFICAÇÃO E ANÁLISE DE SUPERFÍCIES GEOMÓRFICAS REGIONAIS: O CASO DA SERRADE ITAQUERI (SP)
}

\author{
Francisco Sergio Bernardes Ladeira \\ Departamento de Geografia do Instituto de Geociências \\ UNICAMP - Campinas \\ fsbladeira@ige.unicamp.br \\ Marcilene dos Santos \\ FEUC - Faculdade Euclides da Cunha - São José do Rio Pardo, SP
}

\begin{abstract}
Resumo
Tradicionalmente, perfis de alteração foram empregados de maneira indistinta como evidência de superfícies geomórficas de dimensões regionais, fato atualmente questionado por diversos autores. Este trabalho discute as possibilidades e limitações deste procedimento utilizando-se de um exemplo correspondente aos materiais relacionáveis com a Formação Itaqueri sobre a Serra de Itaqueri, nos municípios de São Pedro, Itirapina e Charqueada, no Estado de São Paulo. A Formação Itaqueri, de idade cenozóica, é composta por sedimentos depositados em ambientes de leques aluviais sob condições semi-áridas. As feições morfotectônicas e paleopedológicas remanescentes na área caracterizam uma evolução complexa, envolvendo mudanças climáticas significativas, pulsos de movimentação tectônica distintos e diferentes eventos deposicionais. A análise dos sedimentos e dos paleossolos indica dois eventos deposicionais em ambiente de leques aluviais alternados por períodos de clima mais úmido em que se desenvolveram dois perfis de alteração associados a distintas superfícies; o primeiro, um solo espesso, desenvolvido nos sedimentos associados ao primeiro evento deposicional, sendo atingido posteriormente por um processo de silicificação; o segundo, um perfil laterítico muito espesso, desenvolvido nos sedimentos associados ao segundo evento deposicional. Uma superfície erosiva bem marcada separa ambos materiais. Desta forma existem 3 superfícies geomórficas bem marcadas na área: uma associada à base dos depósitos da Formação Itaqueri que trunca as formações Botucatu e Serra Geral; outra associada ao desenvolvimento de espessos solos que foram silicificados, e outra associada ao desenvolvimento de um perfil laterítico, associada a um espesso ferricrete. Movimentações tectônicas cenozóicas soergueram e abateram a área sucessivamente, implicando inversão de relevo, destruição parcial dos sedimentos e dos paleossolos e posicionamento altimétrico diferenciado ao longo da área.
\end{abstract}

Palavras-chave: Superfície geomórfica; Paleossolo; Formação Itaqueri.

\begin{abstract}
The Itaqueri Formation, Cenozoic, is located in Itaqueri's Hill, Southeast of Brazil. It is composed by sediments deposited in environment of alluvial fans under semi-arid conditions. The remains of morphotectonic and paleopedological features in the area characterize a complex evolution that involves important climate changes, different episodes of tectonic motion and different positional events. The analysis of sediments and paleosoils indicates two events of deposition of alluvial fans alternated by periods of climate more humid in which developed two alteration profiles. The first profile developed a thick Ultisol (US Soil Taxonomy) in the sediments associated to the first depositional event that was subsequently reached by a silicification process. The second profile developed a very thick lateritic feature in the sediments associated to the second depositional event. The analysis of alteration profiles and paleosoils indicates three geomorphic surfaces in the area: the first associated to basal deposits of Itaqueri Formation wich truncated the Botucatu Formation and Serra Geral Formation; the second associated to the development of soil wich were silicified later; and the third associated to development of a lateritic profile. A distinctive erosional unconformity separates both materials. Cenozoic tectonic motions uplifted and lowered the area successively which implied relief inversion, partial destruction of the sediments and paleosoils, and exposures in different altitudes along the area.
\end{abstract}

Key Words: Geomorphic surface; Paleosol; Itaqueri Formation. 


\section{Introdução}

A existência e a importância de extensas superfícies erosivas na elaboração do modelado no Estado de São Paulo e em toda a Região Sudeste durante o Cenozóico foram ressaltados já há décadas por Ab'Saber (1954), King (1956) e inúmeros pesquisadores que se seguiram, inferindo suas idades relativas e seus respectivos significados ambientais, caracterizando-as como produtos de eventos de longa duração, utilizando-as para balizamentos em correlações regionais.

A região das Serras de Itaqueri e São Pedro no Estado de São Paulo é exemplar para a observação de superfícies geomórficas. Esta área é identificada como a zona das cuestas (IPT, 1981) apresentando evidências de superfícies identificáveis no seu reverso imediato e aquelas posicionadas no interior da Depressão Periférica Paulista, estas separadas por uma escarpa da ordem de centenas de metros. O topo destas Serras chega a alcançar 1.060 metros de altitude.

A superfície que define o topo das cuestas corresponde à Superfície Sul Americana ou do Japi (Penteado, 1968; Melo e Ponçano, 1983), cuja esculturação é comumente atribuída ao Cretáceo Superior e Terciário Inferior. Tais trabalhos destacam a questão evolutiva destas áreas, porém nem sempre abordam a questão dos materiais associados a estas superfícies, como sedimentos ou perfis de alteração, com um suficiente detalhamento.

A associação entre superfícies geomórficas e perfis de alteração foi proposta e utilizada por alguns autores (Firman, 1994; Andreis, 1981) e criticada por outros (Twidale e Bourne, 1998; Brown et al. 2000; Corrêa e Mendes, 2002). A proposta deste trabalho é, a partir de um estudo de caso, destacar as possibilidades e limitações do uso de perfis de alteração para a interpretação da evolução geomorfológica em escala regional, da ordem de dezenas de quilômetros.

Segundo Ab'Saber (1998), trabalhos que adotam tal abordagem são multidisciplinares, assim, no caso deste estudo, são utilizadas e relacionadas informações sedimentológicas, estratigráficas, tectônicas e paleopedológicas. Particularmente na área estudada, a necessidade de estudos multidisciplinares tornou-se muito relevante devido à complexidade geológica (tectônica e estratigráfica) e de perfis de alteração/pedogênese (ferricretes e silcretes) nela presentes, que dificultaram um consenso entre os pesquisadores a respeito da sua evolução geomorfológica.

Além disso, soma-se a isto a descontinuidade no espaço e no tempo de maior densidade de informações e registros relativos às paleoalterações, um fator complicador na reconstituição da evolução geomorfológica. De qualquer forma, como destacam Thiry et al. (1999:3) "os estudos de paleointemperismo contribuem para a reconstituição paleoambiental e paleogeográfica, correlações de depósitos regionais, taxas e épocas de soerguimento/erosão e inventários de jazidas minerais".

Em face de tais questões, este trabalho discute alguns estudos abordando a interface superfície pretérita / perfis de alteração, comumente praticada em alguns países (com destaque para a Austrália), mas ainda pouco explorada no Brasil. Para tanto, fez-se necessário iniciar este artigo por uma revisão mais extensa da literatura envolvendo o uso de paleossolos e da relação paleossolo/superfície geomórfica na reconstituição de paleopaisagens, para, na sequiência, ser demonstrada a contribuição de tais procedimentos para a interpretação da evolução geomorfológica do Terciário na área da Serra de Itaqueri (compreendida entre as coordenadas $47^{\circ} 45^{\prime}$ e $48^{\circ} \mathrm{W}$ e $22^{\circ} 22^{\prime}$ e $22^{\circ} 30^{\prime} \mathrm{S}$ ), nos municípios de Itirapina, São Pedro e Charqueada, no Estado de São Paulo.

Trata-se, aqui, de um trabalho no âmbito da paleopedologia, cujo objeto de estudo, os paleossolos, quando relativamente preservados, são importantes indicadores das condições ambientais pretéritas das paisagens geomorfológicas, servindo também como parâmetros para a identificação de processos erosivos e deposicionais correlativos e posteriores à sua formação.

\section{Principais métodos de campo da paleopedologia}

Inicialmente, faz-se necessário distinguir duas terminologias empregadas neste trabalho. A primeira, perfil de alteração, é utilizada neste trabalho com um sentido de um volume rochoso que passou por processos intempéricos, especialmente de natureza química, resultando em espessos mantos de intemperismo, não raro com dezenas de metros de espessura. Assim, estes mantos, quando de sua formação, incluem o solo posicionado em seu topo, bem como o material subjacente alterado em condições supérgenas, mas sem a presença de estruturas tipicamente pedológicas. É o caso do perfil laterítico abordado neste trabalho, que chega a 60 metros de espessura, porém o solo a ele associado, há muito foi eliminado pelos processos erosivos. A segunda, paleossolo, como o material que, mesmo litificado, apresenta evidências biogênicas (como marcas de raízes e de atividade de animais escavadores) e estruturas tipicamente pedológicas. Ambos materiais são objeto de estudos da paleopedologia.

A Paleopedologia é o estudo de solos antigos, tendo por objeto solos soterrados e/ou incorporados a seqüências sedimentares, ou ainda solos desenvolvidos em superfícies de relevo pretéritas (Andreis, 1981) e que, embora tenham permanecido na superfície e sido influenciados por mudanças ambientais posteriores (Retallack, 1990), evidenciam antigos ambientes e contêm registros sobre as ações do clima, a cobertura vegetal, as formas de relevo, a intensidade da pedogênese e as taxas de sedimentação vigentes quando da sua formação (Wright, 1992; Kraus, 1992). Segundo Andreis (1981), paleossolos são solos que se formaram em superfícies de relevo do passado. Para Meyer (1987) paleossolos são solos cujas condições responsáveis por sua gênese não são mais as vigentes atualmente. Tais solos são fósseis se estão sob rochas mais jovens; caso contrário, se expostos, 
estes solos, por não estarem em equilíbrio com o meio ambiente atual, tendem a se degradar.

Para uma classificação inicial de paleossolos, uma primeira tipologia, mais simples, foi sintetizada por Andreis (1981), a partir de diversos autores, podendo ser reconhecidos três grandes tipos:

-solos reliquiais correspondem aqueles que permaneceram expostos, desde sua formação em ambientes antigos até os dias de hoje, assim, suas propriedades resultam da somatória de processos pedológicos superpostos que se sucederam neste espaço de tempo;

-solos soterrados são aqueles formados em uma superfície de relevo pretérita, recobertos por depósitos sedimentares, sendo sua gênese independente das condições ambientais existentes na superfície atual, pois suas características pedológicas ficaram preservadas pelo soterramento. Portanto, a evolução dos solos soterrados pré-quaternários é o resultado dos processos pedogenéticos anteriores ao soterramento profundo do solo e à subseqüente transformação por diagênese incipiente deste;

·solos exumados são solos que estiveram soterrados e guardaram suas características pedológicas durante um certo tempo e posteriormente foram expostos à nova pedogênese, mais recente, em decorrência da erosão dos materiais sobrepostos.

A interpretação genético-ambiental dos perfis de paleossolos desenvolvidos sob condições ambientais pretéritas, distintas das condições atuais, implica certa complexidade, apesar destes solos terem se desenvolvido sob processos que basicamente podem ter sido similares àqueles vigentes nas diversas paisagens pedológicas atuais (Firman, 1988). Isto é devido à dificuldade no reconhecimento de uma série de processos posteriores que os afetaram, como alterações decorrentes da superposição de diferentes processos pedogenéticos sucessivos (perfis poligenéticos) e/ou da ação de processos diagenéticos posteriores (ANDREIS, 1981).

Devido a tal complexidade envolvendo a análise de paleossolos, notadamente dos pré-quaternários, Wright (1992) propôs algumas características, que denominou de feições diagnósticas, as quais podem ser utilizadas na interpretação de paleossolos. Tais características correspondem àquelas associadas aos processos de iluviação, eluviação, gleização, às marcas de raízes e também à estrutura, sendo estas feições correlativas ao desenvolvimento pedológico antecedente ao soterramento do solo. Portanto, podem ser utilizadas nos estudos paleopedológicos como indicadores diagnósticos dos processos atuantes à época de sua formação. Entretanto, outras feições comuns em solos podem não ser consideradas diagnósticas de uma antiga pedogênese, se forem fruto de evolução posterior ao soterramento do solo, pois seriam correlativas aos processos diagenéticos que se seguiram, como a rubefação, des- truição das evidências de estratificação, formação de crostas, mosqueados e outras. As feições de hidromorfia, por exemplo, podem estar associadas à oscilação do lençol freático atual, posterior à paleopedogênese e até à diagênese, dentro do próprio pacote sedimentar.

Apesar de tais dificuldades, algumas metodologias, provenientes de áreas de pesquisa correlatas, foram sendo incorporadas por alguns autores e modificadas ou adaptadas para o estudo específico dos paleossolos.

A primeira contribuição é de escala megascópica, advinda das análises sedimentares e pedológicas. Alguns autores como Andreis (1981) destacam que o desenvolvimento de solo, dentro de uma seqüência sedimentar, implica ambientes com baixa energia de sedimentação, pois ambientes com forte a moderada energia de sedimentação são desfavoráveis à sua formação, já que o aporte de sedimentos seria intenso, além de facilitar a erosão dos materiais pedológicos, sendo eventuais nestes registros sedimentares, os solos decaptados. Nessa escala de trabalho mais detalhada, alguns autores (Yallon e Walker, 1988 apud Retallack e Mcdowell, 1988) vêm trabalhando com "paleocatenas" em materiais préquaternários, indicando a seqüência típica de paleossolos em determinadas situações. Apesar desses casos estudados significarem importante contribuição, estes trabalhos não são comuns, pois raramente são encontradas seqüências contínuas de exposição para este tipo de análise.

Decorrentes das análises sedimentares megacóspicas, diversos trabalhos recentes abordam a pedofácies, termo introduzido por Bown e Kraus (1987) para designar a variabilidade lateral dos solos, indicativa de variabilidade lateral de condições ambientais, tais como umidade do solo, topografia, vegetação, taxa de sedimentação etc.

Outra característica é a aparente ciclicidade existente em depósitos continentais (Andreis, 1981). Esta ciclicidade permite a existência de sucessões de paleossolos, sempre que haja algum hiato no processo de sedimentação, e geralmente estão associados a uma diminuição da granulometria dos sedimentos, indicativa de ambiente menos enérgico. Esta situação permitiria que os paleossolos marcassem paleosuperfícies e, portanto, descontinuidades litológicas (KRAUS, 1992; FIRMAN, 1994).

Característica também importante é a espessura do solo desenvolvido que irá variar conforme os ciclos de deposição/não deposição em determinado local. Para Kraus (1992), solos pouco espessos indicam um ciclo curto, enquanto perfis muito espessos e mais desenvolvidos indicam grandes hiatos deposicionais, os quais testemunhariam, portanto, discordâncias importantes. Episódios de não deposição de curta duração estão, na maioria das vezes, relacionados a fatores locais e não causam grandes hiatos deposicionais, enquanto episódios longos estão relacionados a fatores extrínsecos mais abrangentes, tais como grandes flutuações do nível do mar, atividade tectônica e alterações climáticas regionais (KRAUS, 1992). 
Entretanto, convém assinalar que nem toda descontinuidade geológica é marcada pela presença de paleossolos. Sua ausência, aliás, pode indicar um curto espaço de tempo de transição entre os eventos degradacional e agradacional, ou ainda que o solo desenvolvido sobre determinada superfície foi totalmente erodido antes de nova fase deposicional.

A presença de um paleossolo associado à discordância, entretanto, pode fornecer importantes informações sobre os eventos deposicionais/erosionais, além das condições ambientais vigentes durante o intervalo deposicional. Áreas com elevadas taxas de sedimentação poderão não desenvolver solo ou apenas um solo raso com seus horizontes pouco desenvolvidos (WRIGHT, 1992; KRAUS, 1992), enquanto áreas que permaneceram por longo tempo sem sedimentação, apresentam perfis pedológicos bem desenvolvidos, indicativos geralmente de importantes discordâncias sedimentológicas (WRIGHT, 1992) e capazes de fornecer informações ambientais mais completas sobre o período de não deposição.

Além destas observações realizadas em campo, advindas das técnicas sedimentológicas/estratigráficas, outras observações seguem técnicas de descrição da pedologia, podendo configurar-se como as mais importantes, se o objetivo for a análise paleopedológica (ANDREIS, 1981; RETALLACK, 1990, 1997). Neste último caso, as descrições de paleossolos, mesmo que litificados, devem conter as informações morfológicas convencionais dos horizontes pedológicos e suas inter-relações, tais como cor e estrutura, além de caracterizar detalhadamente feições pedológicas como concreções ou crostas, quando presentes (ANDREIS, 1981; RETALLACK, 1990, 1997).

Ademais, observações em campo devem considerar que a relação sedimentação/pedogênese é bastante complexa, já que além dos processos pedogenéticos envolvidos na formação do solo, ocorrem mais ou menos concomitantemente processos de deposição e erosão, podendo criar uma seqüência vertical e lateral de solos superpostos, levando muitas vezes, à superposição de processos pedogenéticos, resultando em perfis poligenéticos (MORRISON, 1967; WRIGHT, 1992; KRAUS, 1992).

O desenvolvimento poligenético, ou com apenas um processo de formação, de perfis pedológicos desenvolvidos ou não desenvolvidos, está diretamente relacionado às taxas de sedimentação do ambiente em questão. Para Morrison (1967), os perfis poligenéticos se desenvolvem quando a taxa de deposição é mais lenta em relação à taxa de pedogênese.

Sintetizando, como destaca Andreis (1981), há um consenso sobre os fatores relevantes para as análises de paleossolo: a) as propriedades macroscópicas e sua descrição são essenciais para a identificação de um paleossolo em campo; b) para ser considerado um paleossolo, um determinado "estrato" deve apresentar mais de uma característica pedogênica ou horizontes distintos; c) é indispensável a combinação de informações de campo com as de laboratório, especialmente a micromorfologia, a fim de se obter a caracterização completa dos paleossolos; d) salvo as modificações produzidas pela diagênese, os paleossolos apresentam características macroscópicas e microscópicas semelhantes às encontradas em solos atuais, ou seja, devem ser estudados através dos mesmos métodos adotados na Pedologia.

\section{Paleossolos, perfis de alteração e as superfícies geomórficas}

A importância das formas de relevo na evolução do perfil pedológico é notória e foi estudada por diversos autores, especialmente após os conceitos de catena (MILNE, 1935) e topossequiência (BOULET et al., 1982), que permitiram deduzir que diversos processos pedogenéticos operam ao mesmo tempo em determinada paisagem, noção fundamental que permitiu associar diferentes processos de alteração e permitiu uma melhor interpretação da paisagem e reconstituição da paleopaisagem.

Para Semmel (1989), a função básica dos paleossolos e perfis de alteração, para a geomorfologia, consiste em indicar as condições ambientais sob as quais as formas de relevo evoluíram. Desta forma, estes perfis podem contribuir para a reconstituição de paleopaisagens e especialmente da seqüência temporal destas, pois tais perfis muitas vezes estão inseridos na seqüência estratigráfica. Como afirmam Thiry et al. (1999), as paleopaisagens freqüentemente são policíclicas e apresentam feições de várias idades que correspondem às combinações de sucessivas mudanças nas condições tectônicas e climáticas. Como demonstra SimonCoinçon (1999), a descrição de exumação de antigas superfícies com perfis de alteração associados são bastante comuns na literatura e existem situações que uma mesma paisagem apresenta uma série de superfícies com diferentes processos de intemperismo associados.

Meyer (1987) destaca que as superfícies geomórficas pretéritas correspondem a superfícies ora deposicionais, ora erosionais. Nas superfícies erosionais, correspondentes a paleopaisagens em situação de degradação, não há aportes sedimentares exteriores e, portanto, as paleosuperfícies podem evoluir por tempos mais extensos e assim formar solos mais espessos e desenvolvidos, não raro, em condições tropicais, perfís lateríticos. Entretanto, nestas condições muito raramente os paleossolos podem ser preservados, devido à predominância de processos erosivos, que terminarão por eliminar estes perfís de solos. Normalmente estas condições correspondem às maiores discordâncias erosivas.

Ainda para Meyer (1987) as superfícies deposicionais, em meio continental, recebem aportes periódicos de sedimentos e os paleossolos irão se desenvolver entre dois eventos deposicionais maiores, em uma superfície relativamente extensa. Nestas áreas a presença de paleossolos será comum, entretanto raramente corresponderão a 
paleossolos muito evoluídos, e, mais raros ainda, a perfís lateríticos.

Desta forma, discordâncias representam hiatos deposicionais que podem envolver milhares ou milhões de anos. É preciso um tempo mínimo de estabilidade da paisagem para desenvolver-se um solo associado à discordância. Em alguns casos, os paleossolos marcam discordâncias regionais, sendo espessos e bem desenvolvidos, indicando longos períodos de desenvolvimento de solo e estabilidade da paisagem (KRAUS, 1999). Em outras situações são desenvolvidos solos menos evoluídos que podem indicar discordâncias de menor importância temporal.

A formação de grandes discordâncias é controlada por fatores alogênicos como flutuações do nível do mar, alterações globais ou regionais do clima e processos tectônicos regionais, processos que influenciam os sistemas geomorfológicos em intervalos de $10^{5}-10^{7}$ anos (SUMMERFIELD, 1991).

As discordâncias erosivas geralmente ocorrem em escalas regionais e podem se desenvolver em superfícies irregulares. Conseqüentemente, os paleossolos associados a tais feições podem apresentar mudanças laterais, e estas mudanças podem ser utilizadas para interpretar variações laterais na topografia (KRAUS, 1999).

Os paleossolos podem ser bons indicadores da taxa de acumulação de sedimentos para intervalos estratigráficos pequenos. O grau relativo de desenvolvimento pedogenético é utilizado na determinação da taxa relativa de acumulação de sedimentos e os paleossolos têm sido utilizados para contrastar e comparar taxas de acumulação de sedimentos, num viés qualitativo, em diferentes partes da bacia deposicional (ATKINSON, 1986; PLATT e KELLER, 1992) e ao longo do tempo (KRAUS e ASLAN, 1993; KRAUS, 1997; KRAUS e ASLAN, 1999), e assim na duração cronológica de determinada superfície geomórfica.

Desta forma, a observação da sequiência de perfis de alteração e paleossolos ao longo de seções verticais facilita a interpretação de paleopaisagens (RETALLACK, 1990). A sucessão vertical dos tipos de sedimentos e paleossolos indicam uma sucessão paleoambiental naquele determinado ponto do espaço. Entretanto, tal análise, por si só, não pode fornecer informações sobre a continuidade lateral destes ambientes.

A observação da continuidade lateral nem sempre é simples, pois depende de uma exposição com certa extensão lateral, o que não é fácil encontrar. A reconstituição da lateralidade também é difícil quando se trata de perfis de paleossolos, porém pode ser válida quando se observa grandes perfis de alteração. Neste caso, os perfis lateríticos são importantes indicadores de antigas superfícies, pois só podem evoluir em paisagens de relativa estabilidade em termos tectônicos e climáticos e durante longo tempo cronológico, tornando-se por isso um bom marcador de uma superfície geomórfica, conforme Firman (1994). Esta situação não ocorre com solos mais rasos, pois estariam indicando um tempo de formação menor e conseqüentemente uma posição em superfícies menos estáveis cronologicamente.

Assim, para se realizar uma boa observação dos perfis

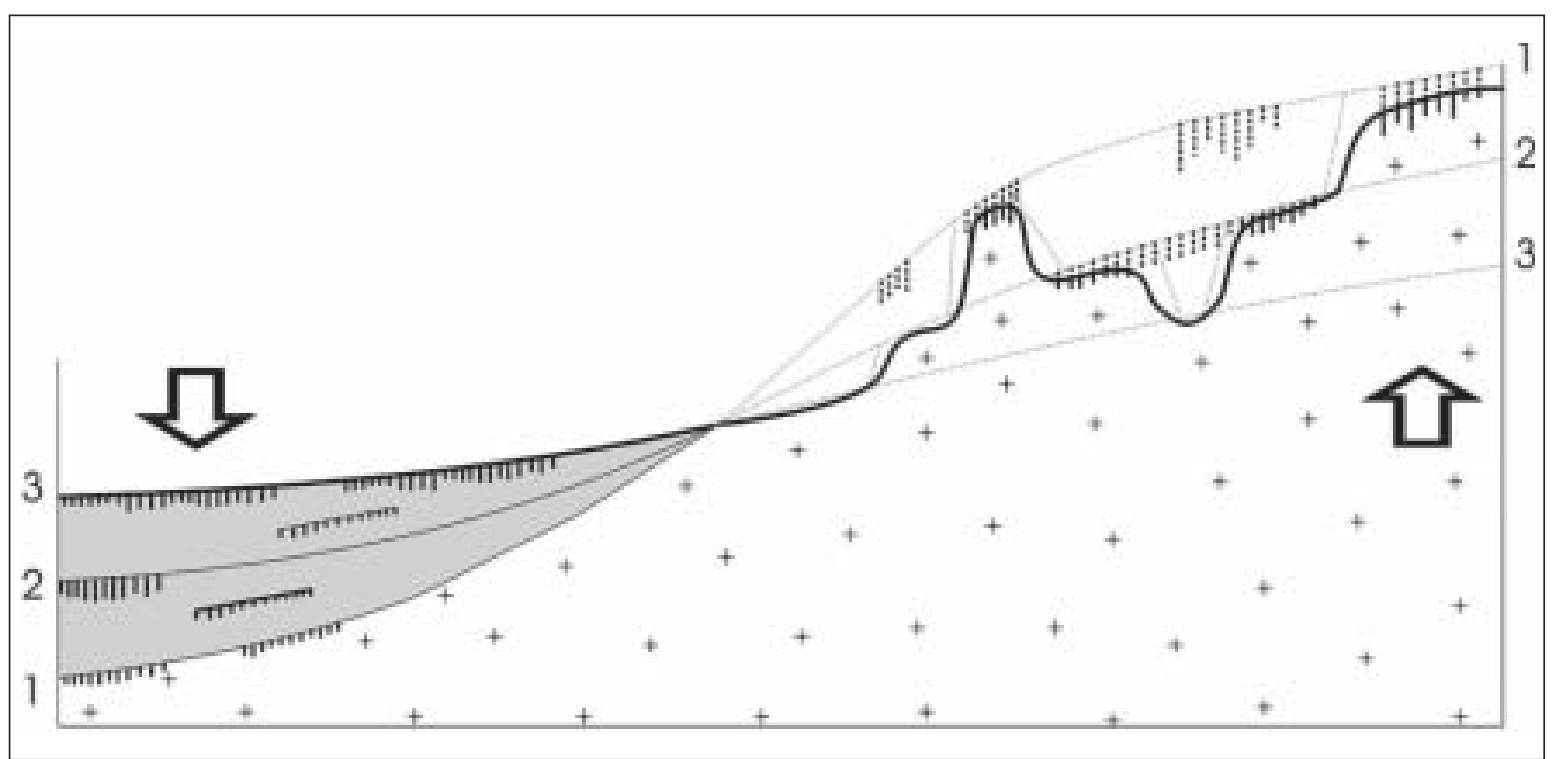

Figura 1: Desenvolvimento de perfis de alteração profundos e bem evoluídos e preservação de paleoperfis ao longo de bacias de margens passivas. Nas áreas de bacia continental, o intemperismo é ativo somente nos períodos de não deposição, o que pode limitar o desenvolvimento dos perfis de alteração, entretanto estes terão maiores chances de preservação. Nos planaltos, o material intemperizado associado ao desenvolvimento de superfícies geomórficas freqüentemente é erodido e destruído.

Fonte: Modificado a partir de Thiry et al., 1999. 
de alteração é fundamental que estes estejam preservados, e quanto mais completos, ou seja, sem truncamentos, mais completa será a interpretação paleoambiental obtida a partir deles, lembrando que sua preservação depende de variáveis climáticas e tectônicas posteriores.

Segundo Thiry et al. (1999), a melhor forma para se observar um paleointemperismo é quando o paleoperfil se encontra inserido em uma seqüência estratigráfica. Estes paleoperfís teriam uma melhor preservação em margens passivas e associados às áreas de bacias. Em áreas onde estivesse ocorrendo processo erosivo associado às superfícies, os perfis seriam formados, mas dificilmente seriam preservados, conforme se pode observar na Figura 1 proposta pelos referidos autores.

Desta forma, quanto mais estável a superfície geomórfica em termos cronológicos, maior será a ação do intemperismo nestas porções estáveis do continente podendo resultar em "assinaturas geoquímicas" significativas como bauxitas (alucretes), ferricretes, silcretes, calcretes etc, permitindo realizar correlações abrangendo grandes áreas, tanto para a estratigrafia como para a interpretação de paleosuperfícies (THIRY, 1999). Também as antigas superfícies continentais estáveis, nas quais ocorrem pequena ou nenhuma deposição ou erosão, podem ser marcadas por paleossolos descontínuos, mas localmente espessos (THIRY et al., 1999), correspondentes aos paleossolos residuais na concepção de Andreis (1981).

Como destacam Thiry et al. (1999), os perfis de paleoalteração compõem o registro geológico, entretanto numerosos componentes são sistematicamente perdidos, levando à constatação de que toda reconstituição paleoambiental é distorcida e incompleta. Isto ocorre porque diversas partes do paleorelevo são fossilizadas de maneira inadequada. As partes mais elevadas da paisagem tenderão a ser eliminadas, exceto no caso de tectonismo que rebaixe a área ou rebaixamento decorrente de colapso cárstico. Em contraste, as porções mais baixas do paleorelevo são normalmente soterradas por depósitos sedimentares, o que facilita a preservação dos perfis de paleoalteração e da antiga topografia associada, o que determina que a paleotopografia melhor preservada será aquela correspondente às porções mais rebaixadas da paisagem.

Thiry et al. (1999) ainda destacam que comumente as porções superiores do perfil também são eliminadas, preservando-se apenas as porções inferiores dos antigos perfis de alteração. Desta maneira, os espessos perfis de alteração evoluídos sob climas quentes e úmidos possuem maior probabilidade de preservação que aqueles evoluídos em climas mais frios e secos de pequena espessura. Este fato normalmente impede a interpretação do perfil completo, resultando na análise dos paleossolos, muitas vezes, restrita aos horizontes $\mathrm{B}$ e/ou $\mathrm{C}$, e o topo dos paleossolos não corresponde exatamente à antiga superfí- cie que deu origem ao solo, mas à superfície que o truncou.

Além disso, as diferenças de perfis pedológicos em determinada paisagem dificultam esta interpretação. Numa escala regional, pode-se observar concomitantemente solos com mais de 3 metros de espessura em uma área plana e, em uma vertente mais acidentada, solos com menos de 20 centímetros de espessura. No caso destes solos posicionados sobre a mesma superfície, ao mesmo tempo, serem incorporados a uma seqüência sedimentar e não apresentarem continuidade lateral no afloramento, poderá resultar em uma interpretação incorreta dos ambientes que geraram estes paleossolos, correndo-se o risco de interpretá-los como dois momentos evolutivos distintos.

Decorrente destas dificuldades, trabalhos como os de Twidale e Bourne (1998), Brown et al. (2000) e Corrêa e Mendes (2002) alertam para os problemas do uso destes perfís de alteração para correlações de superfícies geomórficas. As correlações precisam ser cautelosas, especialmente quando se distanciam os pontos de observação e quando entre os pontos de observação encontram-se em unidades geomorfológicas distintas.

Twidale e Bourne (1998) não descartam o uso de perfís de alteração e crostas associadas como indicativo de superfícies, entretanto indicam ser fundamental a observação da escala de trabalho. Segundo os autores, a correlação é totalmente aceitável quando espessos mantos de intemperismo e/ou crostas estão posicionadas sobre platôs residuais de elevação similar e de lados opostos de vales ou quando há um conjunto de platôs de mesma estrutura e similar elevação acima de áreas adjacentes rebaixadas e restritas a áreas limitadas (Figura 2).

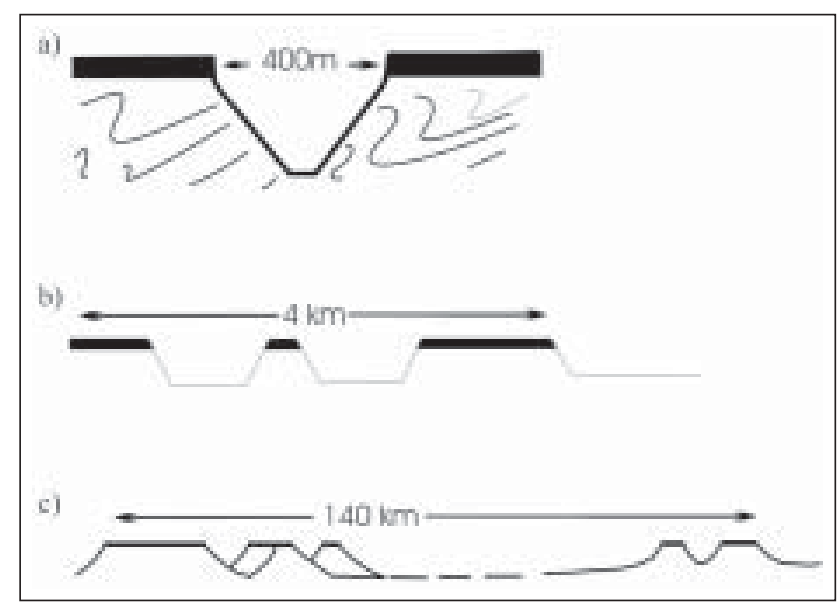

Figura 2: O uso dos paleoperfis para identificação de antigas superfícies pode ser aplicado em algumas situações. Nas situações a e b é possível inferir que o perfil de alteração evoluiu numa mesma superfície, o que não se pode afirmar em c, onde os perfis estão mais distantes e há unidades geomorfológicas distintas entre eles.

Fonte: Modificado de Twidale e Bourne, 1998. 


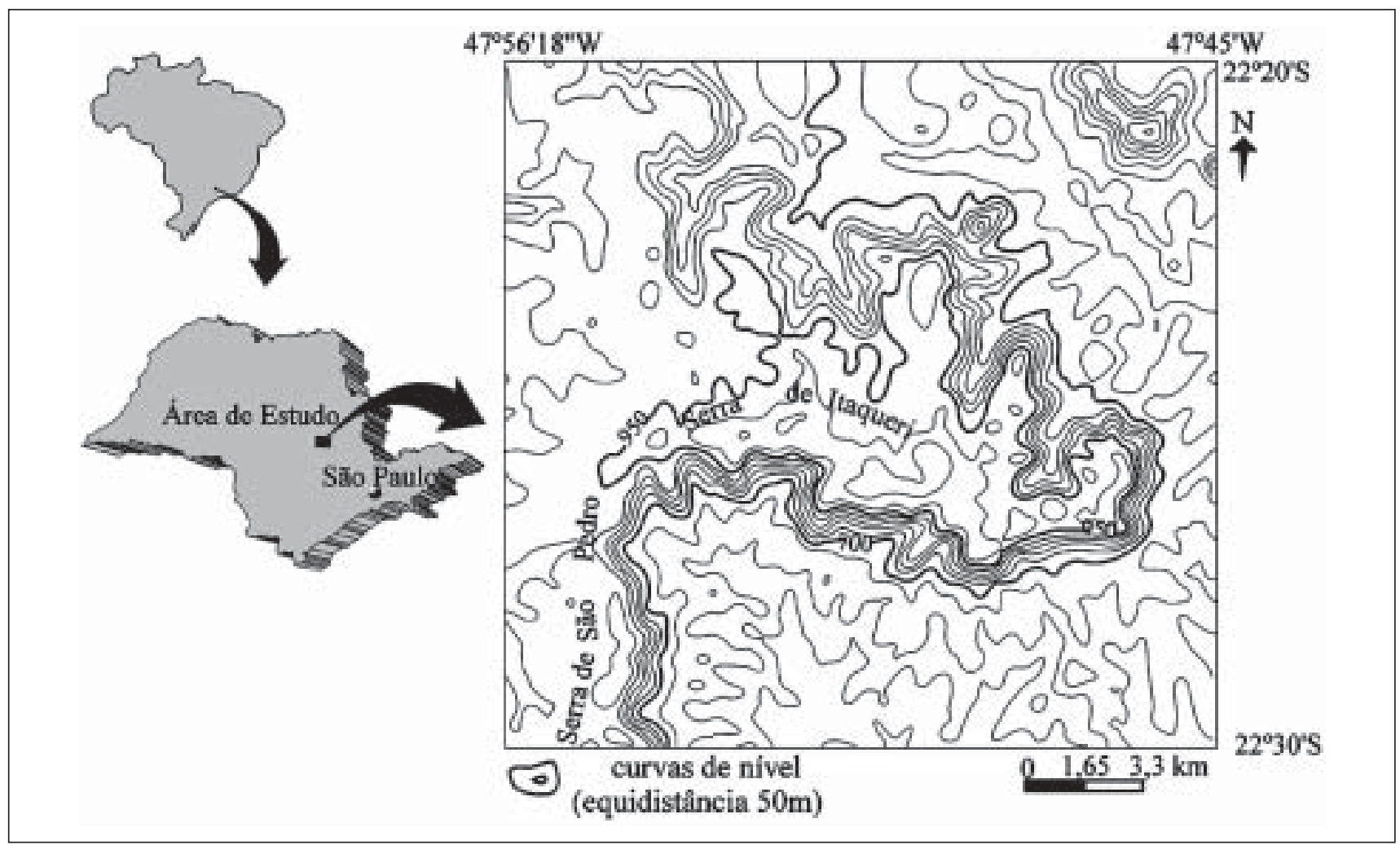

Figura 3: Localização da área de estudo.

\section{Procedimentos metodológicos adotados no estudo de caso}

Com base no exposto, os trabalhos de campo realizados sobre a Serra de Itaqueri e na sua conjunção com a Serra de São Pedro (Figura 3), numa abordagem inicial partiram da escala megascópica, tendo como base cartográfica as cartas topográficas em escala 1:10.000 (IGC-Instituto Geográfico e Cartográfico), objetivando o levantamento e mapeamento de todas as ocorrências (aflorantes e subsuperficiais) de ferricretes, silcretes e perfis lateríticos completos ou parcialmente erodidos e de suas respectivas rochas parentais, bem como as relações de contato entre estes. As altitudes de ocorrência foram demarcadas com um altímetro de Paulling, calibrado ao menos 3 vezes por dia, visando reduzir as alterações resultantes da variação de pressão no decorrer do dia.

Paralelamente, também foram empregados métodos de descrição litológica e estratigráfica (DAVIS, 1983; READING, 1986), pois em alguns pontos constatou-se a presença de algumas estruturas sedimentares preservadas.

Durante esses trabalhos de campo e o mapeamento das ocorrências de silcretes e ferricretes, identificou-se perfis lateríticos sobrepostos ao silcrete, formando uma seção estratigráfica vertical contínua e completa para a área. Estas áreas foram identificadas e selecionadas para observação ainda mais detalhada, através da análise dos sedimentos, dos perfis de alteração e das superfícies associadas a tais materiais.

Numa segunda fase de campo, nesses pontos selecionados procedeu-se à descrição do perfil vertical (em seção) do corte do material, ao registro fotográfico, à confecção de desenhos dos perfis esquemáticos, à descrição morfológica minuciosa dos materiais e a coleta de amostras dos vários extratos, feições e transições, para realização de análises laboratoriais e micromorfológicas posteriores.

Pelo fato do material apresentar-se freqüentemente litificado, foram empregados os procedimentos descritivos propostos por Retallack (1990, 1997), incluindo cor, estrutura, espessura de horizontes e suas relações de contato. Como o ferricrete e o silcrete encontram-se litificados, a textura foi obtida através de pontos de contagem sobre lâminas delgadas petrográficas.

Por fim, procedeu-se à preparação e aos procedimentos de descrição das lâminas delgadas das amostras coletadas nos perfis de alteração / pedogênese representativos da área. Como as amostras estavam litificadas as mesmas foram apenas finamente cortadas, polidas e coladas a lâminas delgadas de tipo petrográfico. As descrições seguiram os critérios de identificação das microestruturas e a nomenclatura proposta de Brewer (1976) e foram realizadas sistematicamente sobre as amostras posicionadas da base para o topo dos perfis, de modo a permitir o acompanhamento da evolução à medida que a pedogênese se desenvolvia para o topo do perfil. Inicialmente, utilizou-se lupa binocular (para separar domínios na lâmina) e depois microscópio óptico petrográfico (com aumentos pequenos e depois maiores para identificação e caracterização dos detalhes das estruturas identificadas, sobretudo transições). As características observadas abrangem o reconhecimento dos constituintes, das 
assembléias, do fundo matricial, da porosidade e das feições pedológicas.

\section{Paleossolos e perfis de alteração sobre a Serra de Itaqueri}

\subsection{Arcabouço geológico}

Os primeiros estudos geológicos sobre a área (Figura 3) remontam a Almeida e Barbosa (1953), quando descreveram os sedimentos que recobrem a Serra de Itaqueri, denominando-os de Formação Itaqueri. Esta formação estaria sobreposta, na área, às formações Serra Geral e Botucatu, pertencentes ao Grupo São Bento do Eo-Cretáceo e JuroTriássico, respectivamente. Estes sedimentos pertencem à Bacia Sedimentar do Paraná.

Almeida e Barbosa (1953) descreveram a Formação Itaqueri como membros alternados de arenitos de matriz argilosa, folhelhos, conglomerados e níveis de arenito intensamente silicificado. Os arenitos são predominantes, sendo os demais termos litológicos de extensão limitada, formando geralmente corpos lenticulares alongados. Camadas de conglomerado, com até 5 metros de espessura, ocorrem na maior parte da formação. Os seixos são bem arredondados, com até 30 centímetros de diâmetro e constituídos predominantemente de basalto, ocorrendo ainda quartzo, calcedônia, quartzito, filito, pegmatito, sílex e folhelho da Formação Corumbataí. Os arenitos apresentam granulação variável, desde termos de textura muito fina passando a siltitos, até arenitos grosseiros de granulação heterogênea, podendo ainda ser arcosianos.

Os autores ainda destacam que esta formação pode atingir até 125 metros de espessura, e nas escarpas da Serra de São Pedro, a 25-30 metros acima da base da série (sic), os arenitos se apresentam silicificados, formando escarpas secundárias bastante nítidas. Como visto, trata-se de uma formação com características extremamente variáveis.

Algo que chama atenção em todas as descrições da Formação Itaqueri é que, em alguns pontos, seus sedimentos se encontram inconsolidados, em outros consolidados, ora correspondendo a materiais silicificados ora ferruginizados. Esta situação motivou a realização de diversos trabalhos, na tentativa de explicar tal diversidade.

Barcelos et al. (1983) e Melo e Ponçano (1983) indicam que as coberturas denominadas de Formação Itaqueri representam uma fase de deposição com extensa e contínua distribuição geográfica, atualmente disposta apenas sobre o atual reverso da cuesta. Segundo estes autores, tais testemunhos apresentam-se, hoje, relativamente isolados, devido à erosão imposta pelos grandes cursos d'água conseqüentes. Concluíram também que esta deposição foi posterior à deposição do Grupo Bauru, evidenciada pela própria inconsistência do material, menos litificado, e as relações de contato observadas nas exposições de Pedregulho e Rubião Júnior.

Para Melo e Ponçano (1983), a Formação Itaqueri, preser- vada no reverso das cuestas, corresponderia a depósitos correlativos à extensa fase de pediplanação que originou a Superfície do Japi, no Paleogeno, constituindo uma superfície com características de degradação e agradação, sendo esta última testemunhada hoje nas áreas do reverso da cuesta. Riccomini (1995; 1997) amplia ainda mais as áreas de ocorrência na região pesquisada, destacando que a Formação Itaqueri compreenderia um conjunto de depósitos de cobertura das Serras de Itaqueri, São Pedro, Santana, Cuscuzeiro e São Carlos, além das ocorrências em Rubião Júnior e do topo da Serra do Mirante, propondo uma idade paleocena-eocena para esta formação, correlativa à formação da Superfície do Japi. O referido autor atribui tal idade a estes sedimentos, com base na proposta de Coimbra et al. (1981) de que os silcretes (arenitos silicificados) são hidrotermais, estando tal hidrotermalismo relacionado à manifestação alcalina de Jaboticabal com idade absoluta de 54 M.a..

O ambiente deposicional desta formação não suscita grandes discussões, pois a literatura destaca que a deposição dos sedimentos ocorreu na forma de leques aluviais, com presença de canais anastomosados, associados a depósitos de corrida de lama e depósitos grosseiros de fluxo de detritos, sob um regime climático árido e semi-árido.

Riccomini (1995) destaca ainda que a erosão pósbasáltica promoveu um aplainamento generalizado, destruindo feições resultantes das atividades precedentes, fazendo com que a Formação Itaqueri se encontre assentada hoje sobre superfície regular, tanto sobreposta à Formação Serra Geral quanto à Formação Botucatu.

Outros autores questionam que o topo da Serra de Itaqueri seja constituído apenas de sedimentos da Formação Itaqueri. Soares e Landim (1976), Brandt Neto et al. (1981), Melo e Ponçano (1983) acreditam que a Formação Itaqueri está recoberta por sedimentos mais recentes, os quais são freqüentemente confundidos com solos. Para Soares e Landim (1976), os sedimentos cenozóicos da Serra de Itaqueri corresponderiam à Superfície Sul Americana, exibindo cor vermelho-escura, reflexo do intenso enriquecimento em ferro.

O quadro evolutivo da área fica ainda mais complexo quando se insere a questão da evolução tectônica da área. Vários trabalhos abordaram esta questão sobre a Serra de Itaqueri e São Pedro (BJORNBERG, 1965, 1969; PENTEADO, 1968; SOARES, 1974; BRANDT NETO et al., 1981; RICCOMINI et al., 1995, 1997; LADEIRA e SANTOS, 1996; LADEIRA, 2001).

Bjornberg (1969) indica que as atividades tectônicas na área são recentes, sugerindo inclusive que podem estar ativas até hoje, devido à ocorrência apreciável de cobertura sedimentar moderna em superfícies adernadas e à existência de minerais secundários estriados ao longo de planos cisalhantes nas áreas brechadas. Ranzani et al. (1972) diminuem esta importância tectônica, pois afirmam que o Planalto de Itaqueri, em seu conjunto, permanece relativamente estável após fases de tectonismo que o soergueram, ou que 


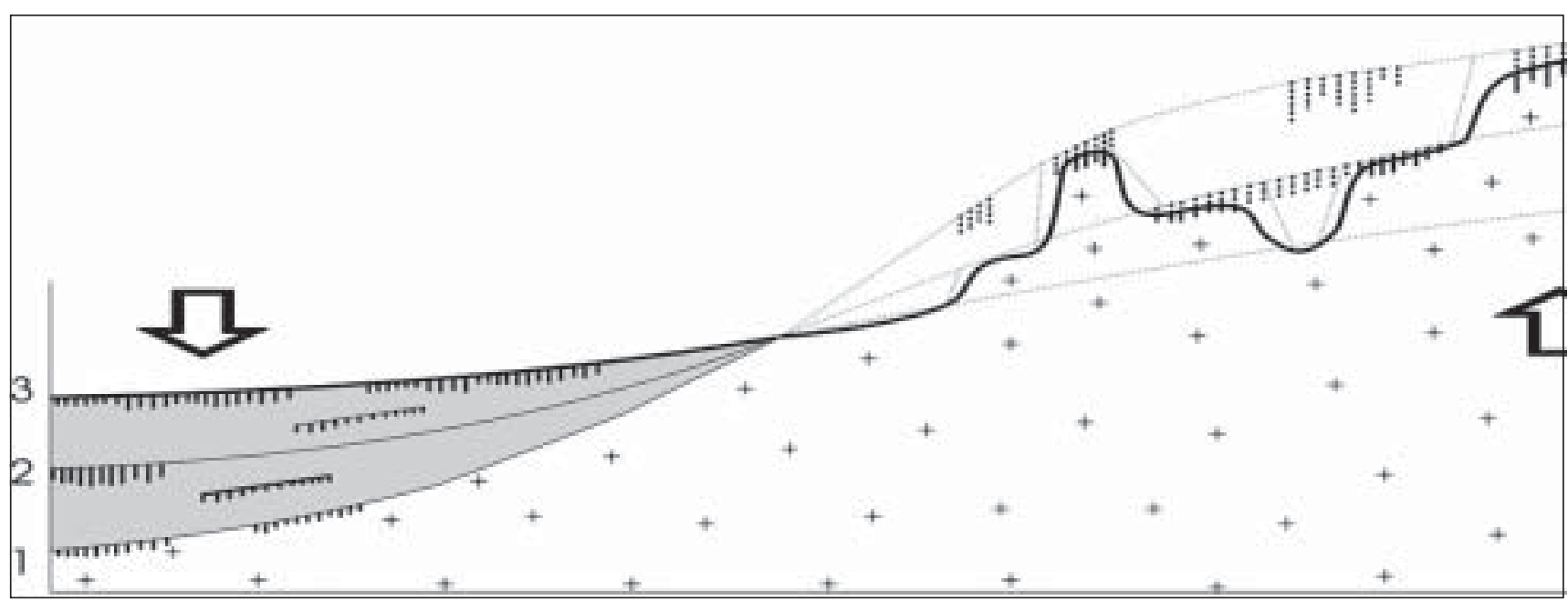

Foto 1: Visão geral do topo do setor sul da Serra de Itaqueri, indicando a seqüência de materiais (corresponde ao perfil da Figura 4).

abateram as zonas circundantes. Brandt Neto et al. (1981) também reconhecem atividades tectônicas posteriores à deposição da Formação Bauru (sic), evidenciadas pelo adernamento de blocos. Ladeira e Santos (1996) corroboram estas afirmativas e destacam as freqüentes ocorrências de ferricretes falhados nestas serras, feições estas associadas a atividade neotectônica, já destacada por Riccomini (1995). Ladeira (2001) indica que os lineamentos que controlam a Serra de Itaqueri refletem em afloramentos através de zonas de falha ou de fraturamento intenso, afetando principalmente os materiais da Formação Itaqueri não silicificada (horizonte caulinítico e ferricretes), raramente os arenitos da Formação Itaqueri silicificada, e por vezes seu embasamento (Formação Serra Geral ou Formação Botucatu).

\subsection{Identificação e análise dos perfis de alteraçãoe paleossolos}

A identificação das áreas de cimeira das serras de Itaqueri e São Pedro e das áreas de ocorrência da Formação Itaqueri mapeadas em trabalhos anteriores (COTTAS e BARCELOS, 1981; BARCELOS et al. 1983), nortearam a delimitação de uma porção correspondente às porções centrais e mais elevadas da Serra de Itaqueri, onde os sedimentos e paleossolos ainda preservam seu empilhamento original sem se apresentarem truncados pelos processos erosivos mais recentes (Foto 1).

As seqüências analisadas apresentam um pacote com cerca de 130 metros de espessura (na área mais preservada), com discordâncias erosivas regionais delimitando os diferentes pacotes sedimentares e paleossolos (Figura 4).

A análise dos sedimentos possibilitou a identificação de três superfícies muito nítidas, com as seguintes características:

- Superfície basal da Formação Itaqueri truncando e nivelando, na área, as formações Botucatu e Serra Geral, e apresentando espessa cascalheira que corresponde à porção basal dos sedimentos da Formação Itaqueri;

- Superfície de truncamento que cortou os paleossolos, silicificados, bem desenvolvidos, apresentando-se sobreposto por novo evento deposicional, em clara discordância erosiva;

- Superfície de cimeira, à qual está associado o perfil laterítico composto no topo por ferricrete, horizonte caulinítico logo abaixo, o qual afeta o topo dos materiais silicificados sotopostos a este.

Em alguns pontos (especificamente nos topos mais elevados) a seqüência de perfil laterítico encontra-se recoberta por um Latossolo Vermelho Amarelo, espesso, muito argiloso, sem qualquer filiação genética com os materiais típicos da Formação Itaqueri ou do perfil laterítico. Depressões estão sempre associadas a estes materiais de topo.

Observam-se, assim, três superfícies erosivas, das quais duas apresentam depósitos associados, entretanto, parcialmente truncados, com o desenvolvimento de perfis de alteração pretéritos.

As descrições dos perfís permitiram levantar uma seção estratigráfica onde se observa o comportamento dos materiais no sentido leste-oeste, como observado na Figura 5.

$\mathrm{Na}$ seqüência de perfis realizados sobre a Serra de Itaqueri, estas superfícies basicamente são contínuas lateralmente, mudando suas cotas altimétricas e as espessuras dos materiais. Merece destaque o desaparecimento do material silicificado para leste, indicando que uma superfície erosiva truncou estes materiais antes da deposição dos sedimentos que foram ferruginizados, ou esta área constituía um alto e não houve a deposição dos materiais correspondentes ao primeiro leque aluvial os quais apresentam-se silicificados.

Outro fato que merece destaque é a ocorrência, praticamente na mesma cota altimétrica dos basaltos da Formação 


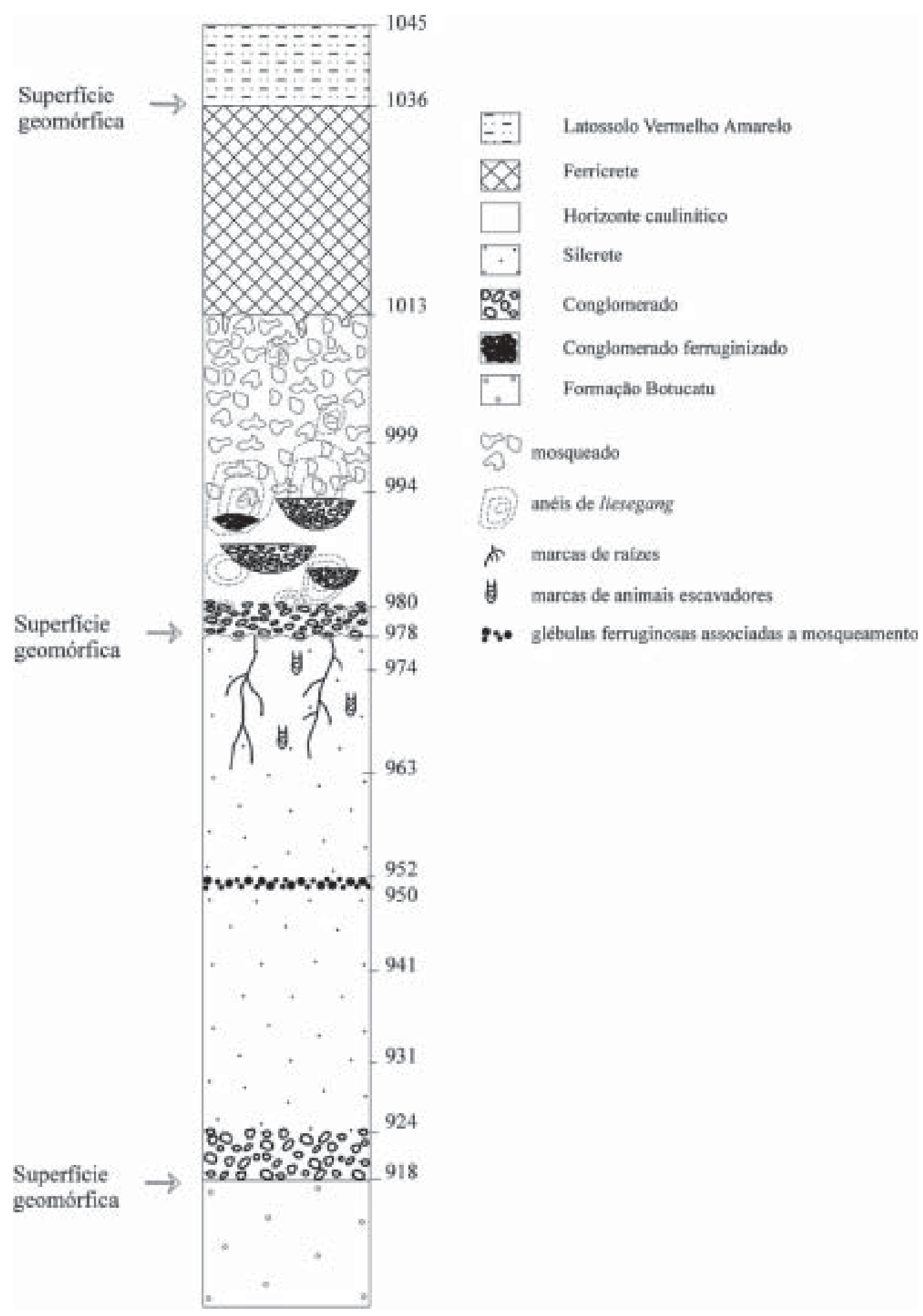

Figura 4: Caracterização de uma seção típica sobre a Serra de Itaqueri.

Serra Geral e arenitos da Formação Botucatu, posicionados lado a lado por tectônica pré-deposição da Formação Itaqueri e posteriormente truncados por uma superfície erosiva dando origem a uma discordância sobre a qual depositou-se a Formação Itaqueri.

\subsubsection{Perfil silicificado}

$\mathrm{Na}$ área da Serra de Itaqueri os sedimentos silicificados chegam a apresentar cerca de 40 metros de espessura. Os 


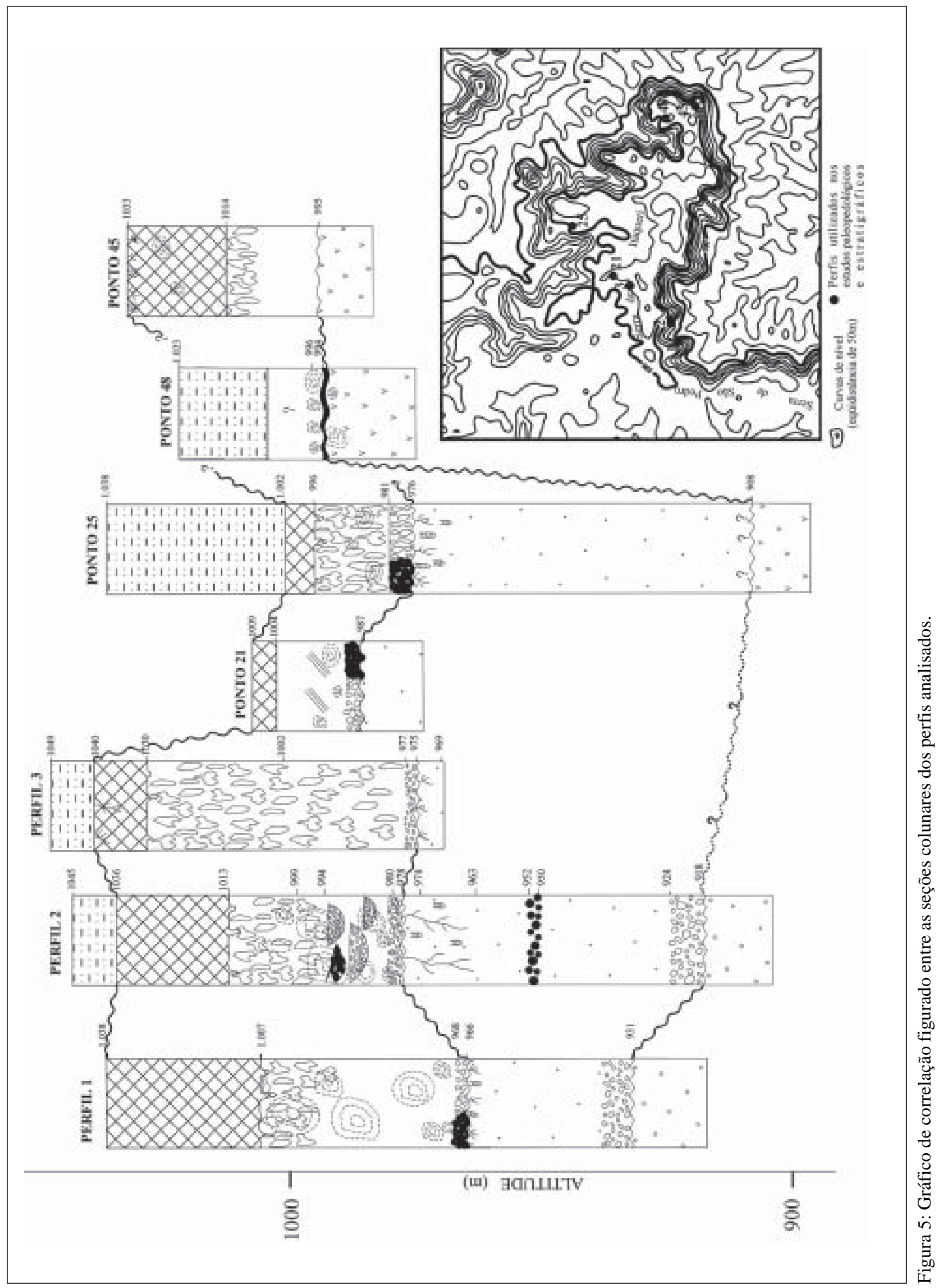


sedimentos são predominantemente arenosos, com seixos esparsos na matriz, exceto em sua base onde ocorre um conglomerado de cerca de 5 metros de espessura. $\mathrm{O}$ material encontra-se silicificado ao longo de todo o pacote, apresentando diminuição de resistência em direção a base.

$\mathrm{Na}$ superfície associada a estes sedimentos silicificados são observados paleossolos que apresentam estruturas pedológicas observáveis tanto macro como micromorfologicamente. Em campo observam-se estruturas prismáticas (Foto 2 ) correspondentes a horizontes $\mathrm{Bt}$ e abundantes marcas de raízes (Foto 3) e também de animais escavadores, enquanto micromorfologicamente encontram-se cutãs indicando iluviação (Foto 4), krotovinas (Foto 5), nódulos ferruginosos e porosidade escavada pela microfauna.

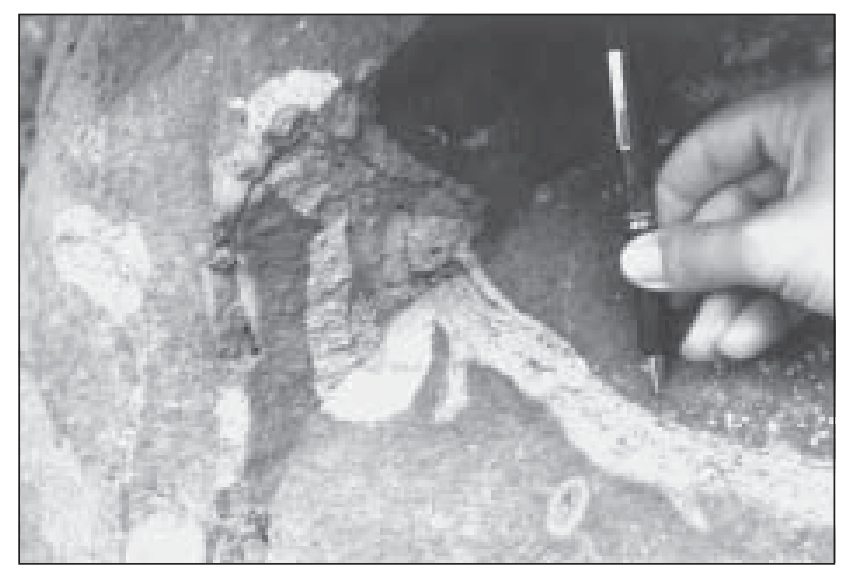

Foto 2: Porosidades de raízes apresentado feições de redução (porções mais brancas) no arenito da Formação Itaqueri silicificada.

Em algumas exposições dos materiais silicificados observam-se paleossolos que chegam a 8 metros de espessura, indicando uma superfície bastante estável para o desenvolvimento de um solo desta espessura. Todos os perfis observados estão truncados em seu topo (normalmente sem horizonte A) e todos estão silicificados. Acima desta superfície observa-se uma cascalheira não silicificada, entretanto eventualmente pode estar ferruginizada pela evolução do perfil laterítico posterior.

\subsubsection{Perfil Laterítico}

A superfície de cimeira, na área da Serra de Itaqueri, corresponde ao topo do perfil laterítico. Este perfil se desenvolve em sedimentos mal selecionados com granulometrias que vão da argila aos seixos decimétricos, porém o material mais comum são arenitos de estrutura maciça. Os seixos estão concentrados em corpos lenticulares no interior do pacote.

Este perfil apresenta uma organização já exaustivamente descrita na literatura (McFARLANE, 1976; TARDY,

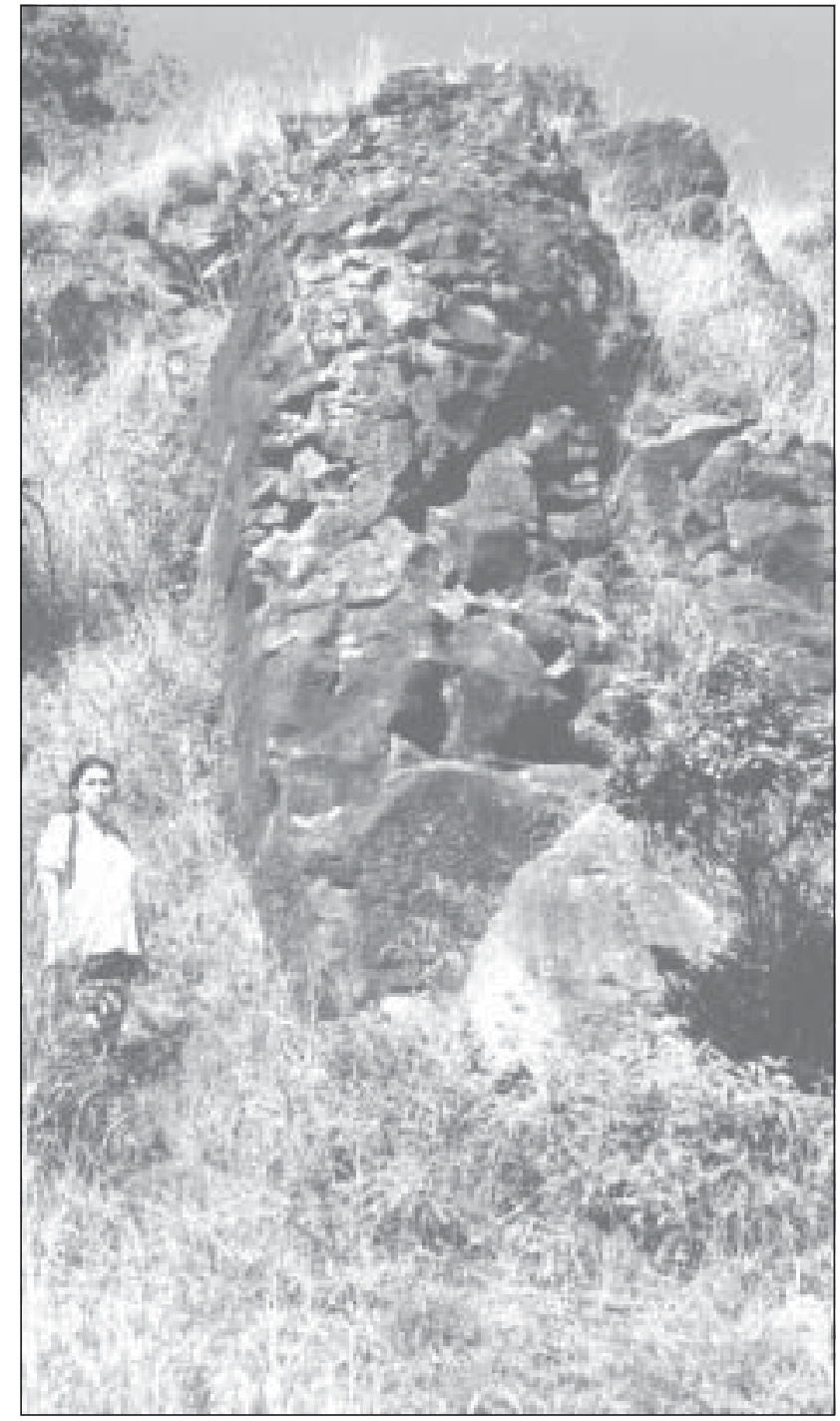

Foto 3: Estrutura poliédrica prismática na porção superior do arenito silificado da Formação Itaqueri.

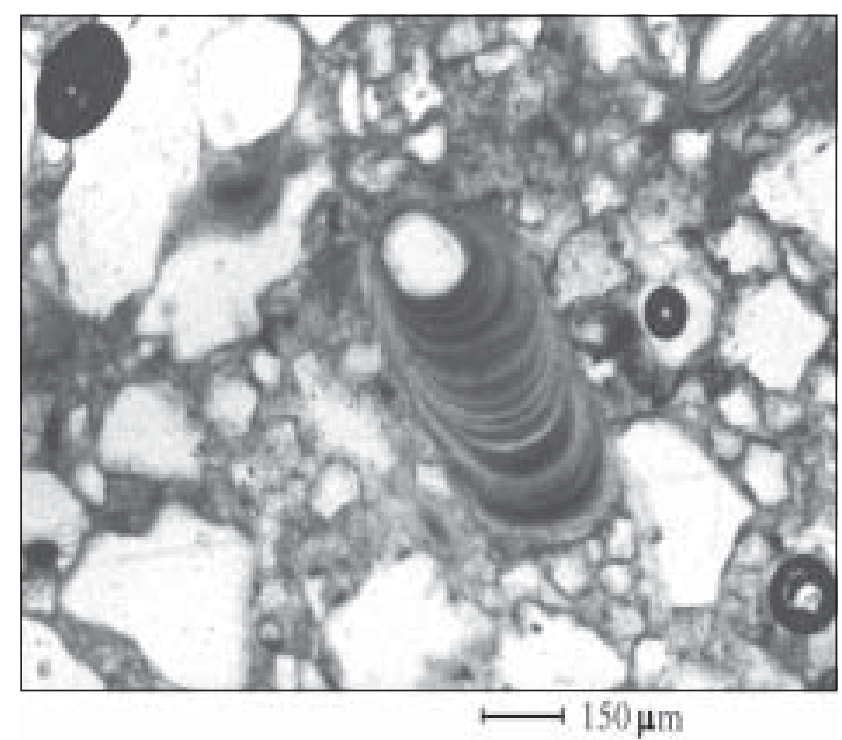

Foto 4: Cutãs de iluviação (ferri-argilãs). Lâmina confeccionada sem impregnação. 


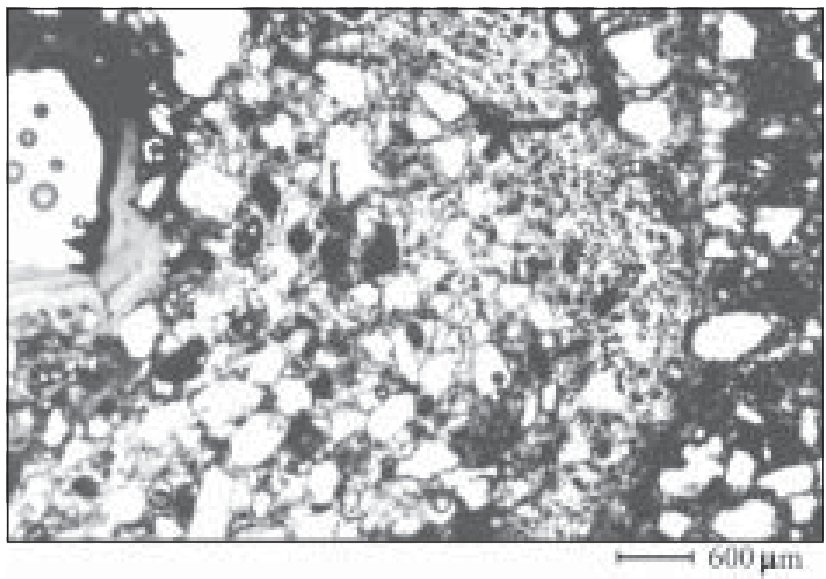

Foto 5: Pedotúbulo (krorovina) apresentando, no centro, porosidade com cutã de iluviação associado e porcao mais clara contendo esqueleto orientado. Observa-se à direita, o limite do pedotúbulo.

1993, entre outros). Trata-se de um ferricrete de estrutura maciça na porção superior (Foto 6) que passa para uma zona de mosqueamento imediatamente abaixo (Foto 7) a qual, por sua vez, dá lugar a um horizonte caulinítico (Foto 8). No interior do horizonte caulinítico é comum a ocorrência de anéis de liesegang ${ }^{1}$ de ferro que podem variar de alguns decímetros até mais de 3 metros de diâmetro (Foto 9).

Comumente esta seqüência, em alguns pontos, ultrapassa os 60 metros de espessura, indicando uma grande estabilidade tectônica e climática, o que demandaria um longo tempo evolutivo, da ordem de milhões de anos como destacam Nahon e Lappartient (1977), configurando uma superfície muito estável e provavelmente com grande extensão geográfica.

\section{Proposta evolutiva}

As discordâncias erosivas regionais, nos sedimentos, nos paleossolos e no perfil de alteração estudados em campo indicam uma evolução das superfícies terciárias presentes na Serra de Itaqueri, conforme apresentadas nas Figuras $6 a$ e $6 b$.

A primeira superfície corresponde à base da sedimentação da Formação Itaqueri e trunca as formações Botucatu e Serra Geral, as quais estão dispostas lado a lado devido à significativa tectônica pós-derrame. Esta primeira superfície teria sido elaborada no período compreendido entre o Cretáceo Médio-Superior e início do Paleógeno (deposição dos sedimentos correspondentes à Formação Itaqueri). Não se evidencia, no campo, qualquer processo de intemperismo associado a esta superfície.

Após este evento, formou-se um embaciamento (de contornos ainda imprecisos) no qual se depositaram os sedimentos basais da Formação Itaqueri, em sistemas de leques aluviais sob um clima semi-árido. Após a deposição ocorre um período de estabilidade em termos deposicionais onde

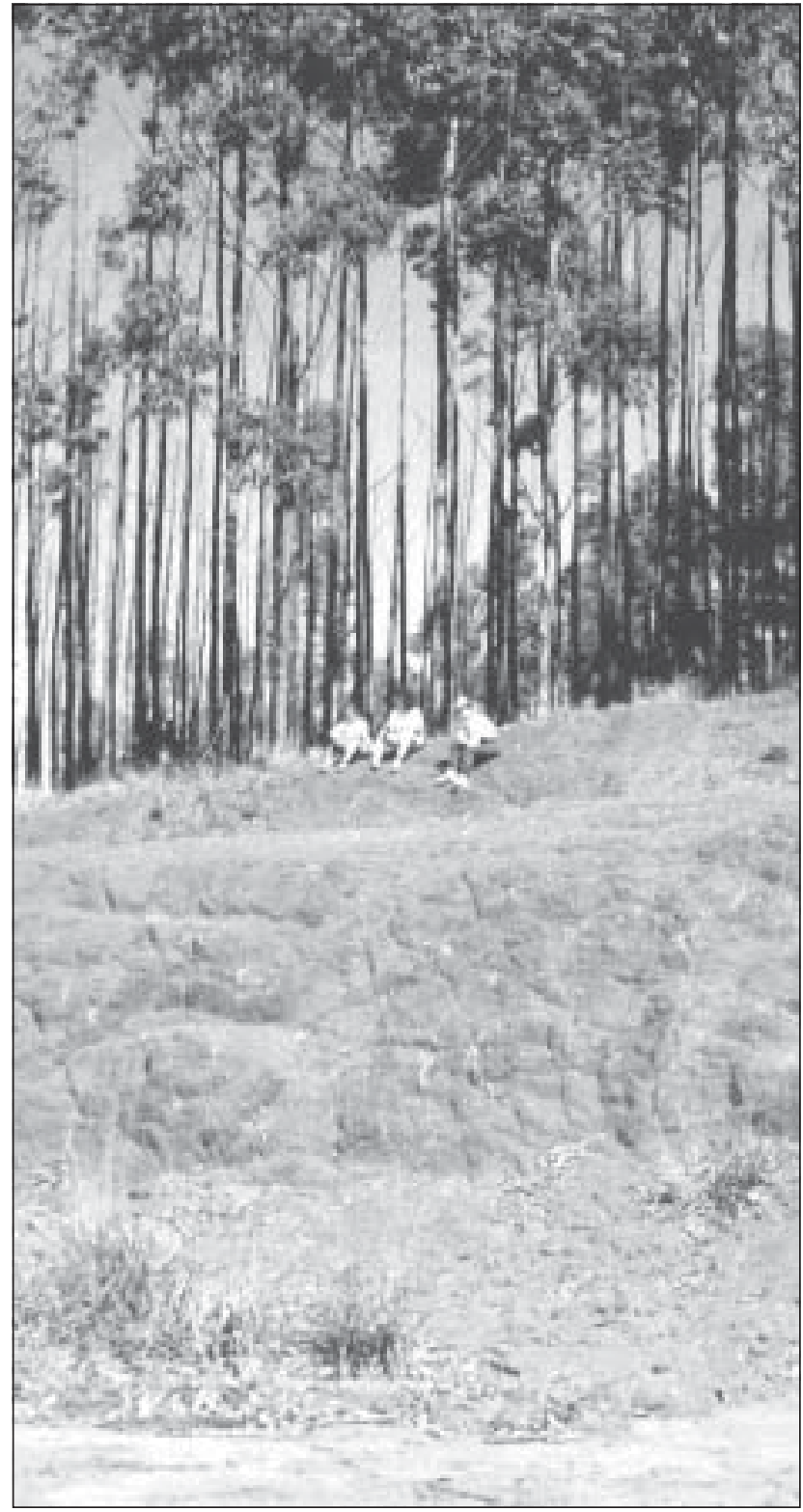

Foto 6: Ferricrete com estrutura maciça.

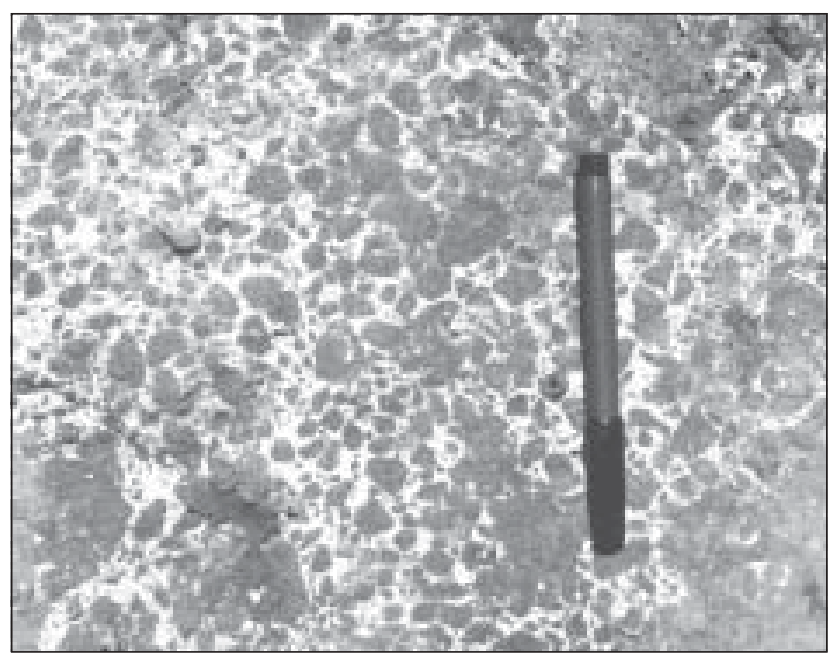

Foto 7: Mosqueamento na porção superior no horizonte caulinítico. 


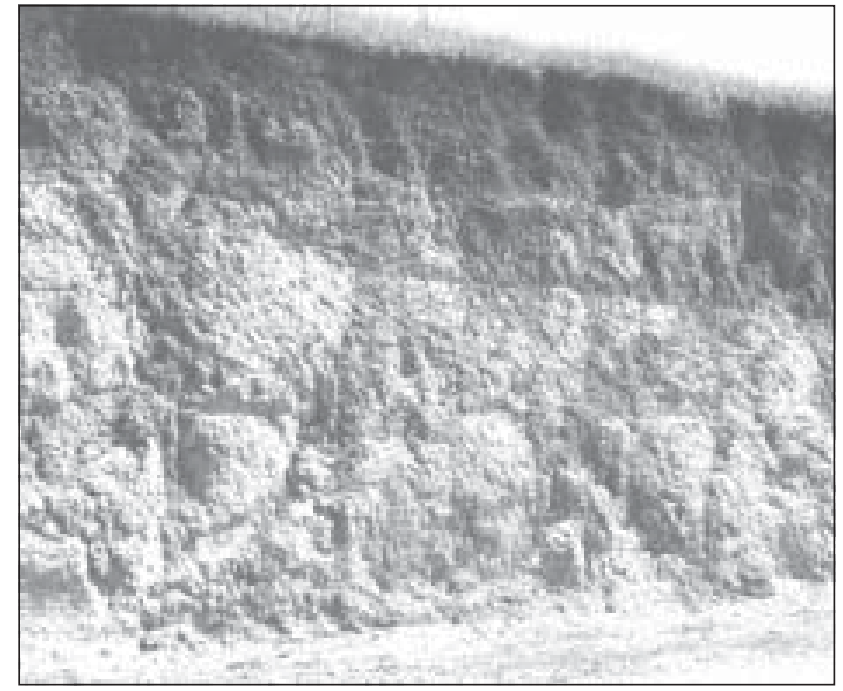

Foto 8: Horizonte caulinítico, apresentando diversas falhas.

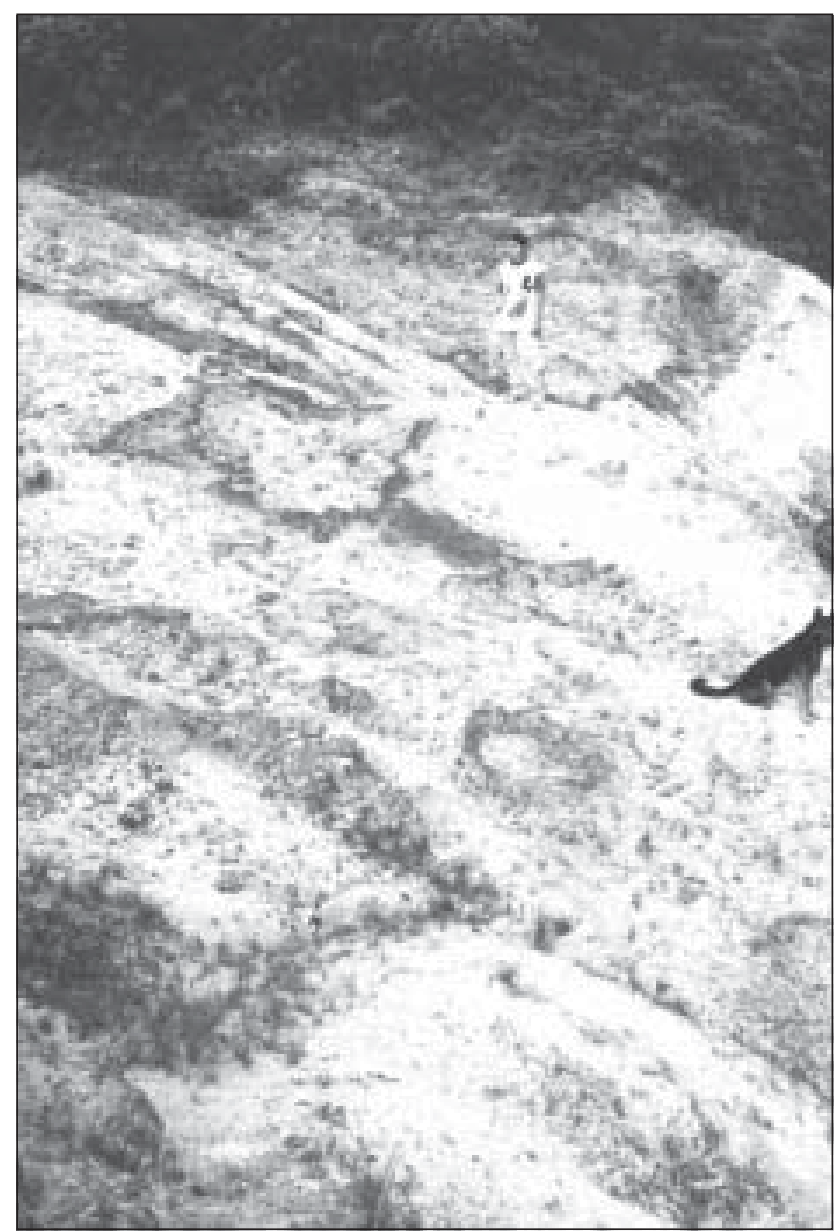

Foto 9: Anéis de liesegang de grande parte no interior do horizonte caulinítico.

se tornou possível o desenvolvimento de espessos solos, caracterizado por um período mais úmido que aquele da deposição dos sedimentos. Nestes espessos solos são identificados processos pedogenéticos indicativos de longa duração de estabilidade da superfície, como processos de iluviação (formando espessos horizontes $\mathrm{Bt}$ ), espessos horizontes de mosqueamento (indicando certa estabilidade de oscilação do lençol freático), além das profundas marcas de raízes, identificadas a mais de 8 metros de profundidade.

Posteriormente, estes materiais passaram por processos de silicificação e ainda foram truncados pela elaboração de uma superfície a qual deu lugar ao novo evento deposicional. $\mathrm{Na}$ área de pesquisa este truncamento é evidenciado pela ausência em todos os pontos de descrição, do horizonte A destes solos, e eventualmente também o horizonte $\mathrm{B}$ foi perdido.

Este novo evento deposicional caracteriza os depósitos superiores da Formação Itaqueri, correspondentes, similarmente ao anterior, a depósitos de leques aluviais. No topo destes depósitos uma nova superfície estável se forma. O clima passa a tropical úmido, com duas estações bem definidas, o que permite o desenvolvimento de um espesso perfil de alteração correspondente a um perfil laterítico, cujo porte (mais de 40 metros de espessura), evidencia um longo período de estabilidade tectônica e climática para se formar. O solo a ele associado foi eliminado pelos processos erosivos posteriores, entretanto, no centro da Serra de Itaqueri ele permanece como testemunho deste evento de longa duração.

Posteriormente a estes processos, a área passa por um soerguimento tectônico significativo que provoca a inversão topográfica da área, hoje realçada a mais de 300 metros acima das cotas da Depressão Periférica Paulista.

\section{Conclusão}

Como já destacado por diferentes autores (RETALLACK, 1990; THIRY et al., 1999 entre outros) os paleossolos e os perfís de alteração podem ser um importante instrumento para a reconstituição paleoambiental com destaque para a reconstituição de superfícies.

$\mathrm{Na}$ área fica evidente a existência de paleossolos do tipo soterrado (ANDREIS, 1981), correspondente aos materiais silicificados e no que se refere ao perfil laterítico a interpretação é mais complexa. Normalmente considera-se que não houve depósitos após a evolução do perfil laterítico, se isto estiver correto a superfície mais elevada da área está associada a um paleossolo reliquial. Entretanto, se considera, como alguns autores (SOARES e LANDIN, 1976; BRANDT NETO et al., 1981; Melo e Ponçano, 1983), que o topo da Serra ainda recebeu depósitos posteriores, então tem-se um paleossolo exumado, pois em várias áreas o ferricrete sustenta as porções mais elevadas do relevo atual.

$\mathrm{Na}$ Serra de Itaqueri estes procedimentos permitiram a identificação de superfícies regionais e associado a estas inferências sobre o quadro paleoclimático que as formaram e notadamente aumentando a complexidade interpretativa sobre a Formação Itaqueri, sempre considerada como evento deposicional único mas que apresenta na metade do pacote sedimentar uma superfície re- 

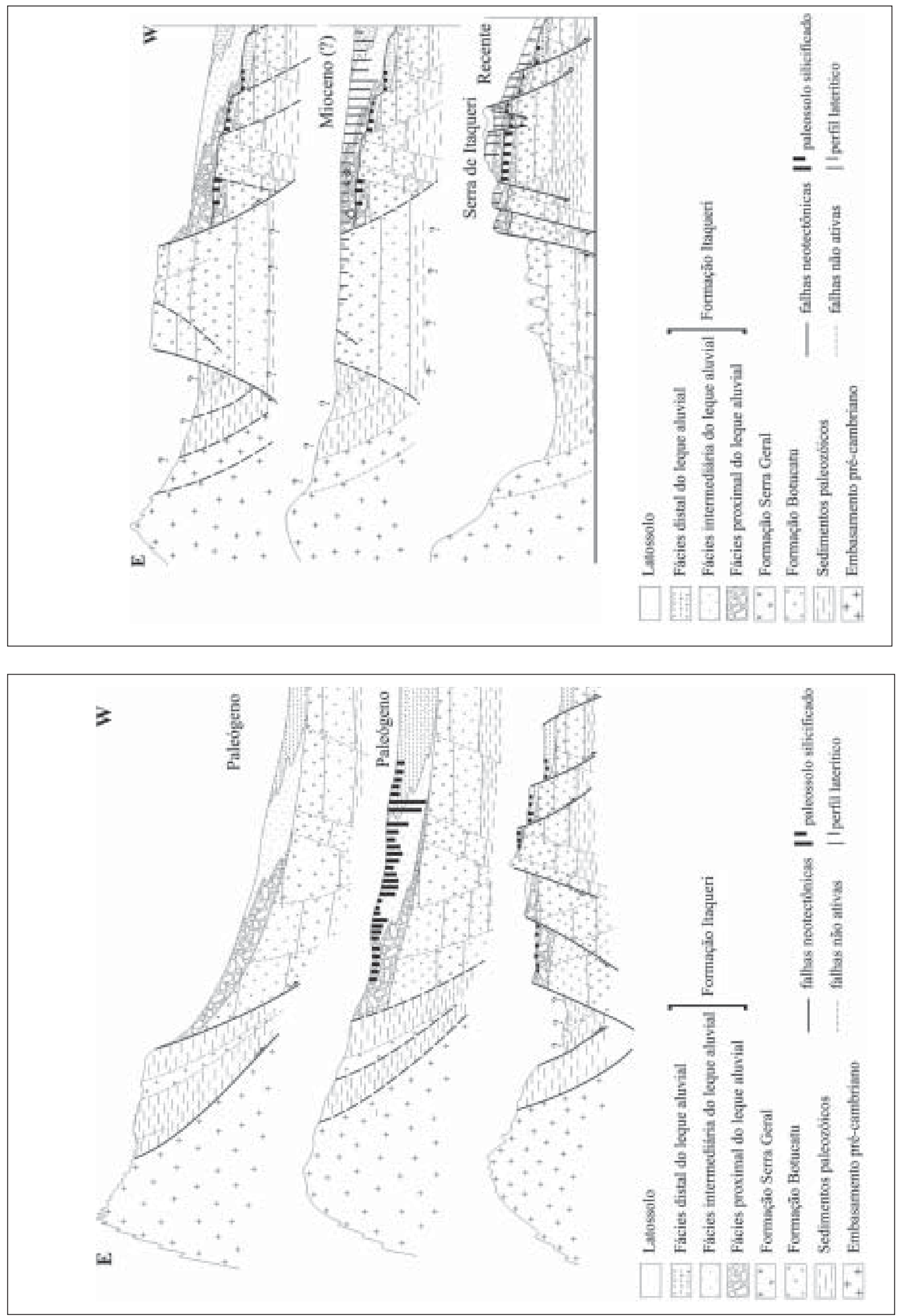

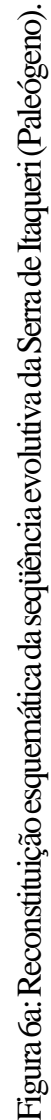


gional evidenciando um significativo hiato deposicional com evolução de espessos perfís de solo e alteração climática.

Destaca-se que o emprego dos perfís de alteração e paleossolos são importantes para se delinear situações de biostasia, ou seja, momentos em que a superfície estivesse estável, sem processos de erosão/deposição. Além disso, seu emprego é praticamente restrito a áreas correspondentes a bacias sedimentares, já que em áreas correspondentes a fontes de sedimentos os processos pedogenéticos seriam repetidamente interrompidos por eventos erosivos e a ausência de sedimentos impediria a incorporação destes solos a uma superfície e conseqüentemente não haveria preservação da superfície e do paleossolo associado.

A associação de dados tectônicos, sedimentares, paleopedológicos e geomorfológicos indicam que a área passou por uma evolução geomorfológica complexa durante o Cenozóico. Os diferentes processos evolutivos sucessivos ao longo do Cenozóico se superpõem, imprimindo grande complexidade ao quadro evolutivo, justificando as dificuldades interpretativas da área.

A Serra de Itaqueri, durante o Cenozóico, passou por dois eventos deposicionais associados a ambiente de leque aluvial sob clima semi-árido. Entre estes dois eventos ocorreram modificações climáticas e geomorfológicas que permitiram a evolução dos paleossolos e perfís de alteração.

Este quadro evolutivo justificaria estudos geológicos mais detalhados para o desmembramento da Formação Itaqueri em duas formações distintas, as quais apresentariam processos deposicionais semelhantes, mas tempos cronológicos de deposição muito diferenciados, separados por um importante hiato deposicional, caracterizados por evidências paleopedológicas, lito-estratigráficas, tectônicas e geomorfológicas.

Também estudos geomorfológicos regionais se fazem necessários para a verificação da expressão lateral destas superfícies, especialmente nas áreas de reverso das cuestas, para validar se estas superfícies geomórficas são correlacionáveis com as outras observáveis, especialmente nas serras de Franca e Botucatu, no Estado de São Paulo.

\section{Agradecimentos}

Os autores agradecem as contribuições significativas e discussões com Selma Simões de Castro e Antônio Carlos Moniz. Pesquisa financiada pelo CNPq, processo 143.339/ 1996-6.

\section{Referências Bibliográficas}

AB'Saber, A. N. (1954) As altas superfícies de aplainamento do Brasil Sudeste. Rev. Fac. Campineiras, 1 (4): 60-67.

AB'Saber, A. N. (1998) Participação das depressões perifé- ricas e superfícies aplainadas na compartimentação do Planalto Brasileiro - Considerações finais e conclusões. Rev IG 19(1/2): 5169.

Almeida, F. F. M. \& Barbosa, O. (1953) Geologia das quadrículas de Piracicaba e Rio Claro, Estado de São Paulo. Bol. Div. Geol. Min., DNPM, n. 143: 196.

Andreis, R. R. (1981) Identificación e Importancia Geológica de los Paleosuelos. Editora da UFRGS, Porto Alegre. $67 \mathrm{p}$.

Atkinson, C.D. (1986) Tectonic control on alluvial sedimentation as revealed by an ancient catena in the Capella Formation (Eocene) of Northern Spain. In Wright, V.P. Paleosols: their recognition and interpretation. Princeton. 139-179.

Barcelos, J. H.; Souza Filho, E. E.; Fulfaro, V. J.; Landim. P. M. B.; Cottas, L. R.; WU, F. T.; Godoy, A. M. (1983) A Formação Itaqueri: um exemplo de tectofácies. In: Simpósio Regional de Geologia, 4, São Paulo, 1983. Atas... São Paulo, SBG, p. 245252.

Barreto, M. M. R. (1970) Geomorfologia da área de São Pedro (SP). Notícia Geomorfológica, 10 (19): 47-61.

BJORNBERG, A. J. S. (1965) Sedimentos pós-cretácicos do leste do Estado de São Paulo. São Carlos, 133p. (Tese de livre-docência), Escola de Engenharia de São Carlos da Universidade de São Paulo.

Bjornberg, A. J. S. (1969) Contribuição ao Estudo Cenozóico Paulista: tectônica e sedimentologia. São Carlos, 128p. Tese (Professor Titular), Escola de Engenharia de São Carlos/ USP.

Boulet, R.; Chauvel, A.; Humbel, F. X.; Lucas, Y. (1982) Analyse structurale et cartographie en pédologie. I. Prise en compte de l'organization bidimensionnelle de la couverture pédologique: les etudes de topossequences et leurs principaux apports à la connaissance des sols. Cah. Orstom, série Pédologie, 19 (4): 309-322.

Bown, T.M.; Kraus, M.J. (1987) Integrations of channel and floodplain suites, I. Developmental sequence and lateral relations of alluvial paleosols. Journal of Sedimentary Petrology, 54(4): 587-601.

Brandt Neto, M.; Coimbra, A. M.; Barelli, N.; Spiller, L. R. (1981) Sedimentos da Serra de Itaqueri: Formação Bauru e cobertura cenozóica. A Formação Bauru no Estado de São Paulo e Regiões Adjacentes, SBG/São Paulo, p. 63-86.

Brewer, R. (1.976) Fabric and Mineral Analysis of Soils. Krieger Publishing Company, 482p.

Brown, R.W.; Gallagher, K.; Gçeadown, A. J. W.; Summerfield, M.A. (2000) Morphotectonic evolution of the South Atlantic margins of Africa and South America. In Summerfield, M.A. Geomorphology 
and Global tectonics. 225-281, Wiley.

Coimbra, A. M.; Brandt Neto, M.; Coutinho, J. M. V. (1981)

Silicificação dos arenitos da Formação Bauru no Estado de São Paulo. In: A Formação Bauru no Estado de São Paulo e Regiões Adjacentes, SBG/ São Paulo, p. 103-115.

Corrêa, A. C. B.; Mendes, I. A. (2002) O problema das superfícies de erosão: novas abordagens conceituais e metodológicas. Revista de Geografia 18(2): 7086.

Cottas, L. R.; Barcelos, J. H. (1981) Novas considerações sobre a geologia da região de Itaqueri da Serra, SP. In SBG-SP - Atas do $3^{\circ}$ Simp. Reg. Geol., Curitiba, 2: 70-76.

Davis, R. A. (1983) Depositional System: a genetic aproach to Sedimentary Geology. Prentice Hall, New Jersey, 669p.

Firman, J. B. (1988) Soil evolution: evidence from Southern Australia. Earth-Science Reviews. 25: 373-386.

Firman, J. B. (1994) Paleosoils in laterite and silcrete profiles evidence from the South East Margin of the Australian Precambrian Shield. Earth Science Reviews, 36: 149-179.

IPT (1981) Mapa Geomorfológico do Estado de São Paulo. IPT, São Paulo, 94 p.

King, L.C. (1956) A geomorfologia do Brasil Oriental - Revista Brasileira de Geografia. 18(2): 3-265.

Kraus, M. (1992) Mesozoic and Tertiary paleosols. In Martini, I.P.; Chesworth, W. (ed.) Weathering, Soils \& Paleosols. Elsevier, Amsterdan, p. 525542.

Kraus, M. (1999) Paleosols in clastic sedimentary rocks: their geologic applications. Earth-Science Reviews, 47: 41-70.

Kraus, M.J. (1997) Lower Eocene alluvial paleosols: pedogenic development, stratigraphic relationships, and paleosol/landscape associations. Palaeogeography, Palaeoclimatology, Palaeoecology, 129: 387-406.

Kraus, M.J.; Aslan, A. (1993) Eocene hydromorphic paleosols: significance for interpreting ancient floodplain processes. Journal of Sedimentary Petrology, 63(3): 453-463.

Ladeira, F. S. B.; Santos, M. Ferricrete terciária falhada na Serra de São Pedro (SP): indicação de movimentação neotectônica. Geociências, 15 (2):445-453, 1996.

Ladeira, F.S.B. (2001) Paleossolos Silicificados na Serra de Itaqueri-Itirapina/SP: subsídios para a reconstituição paleoambiental. Tese de Doutorado, USP/São Paulo (mimeo), 362p.

McFarlane, M.J. (1976) Laterite and Landscape. Academic Press, London, England, $151 \mathrm{p}$.

Melo, M. S.; Ponçano, W. L. (1983) Gênese, Distribuição e Estratigrafia dos Depósitos Cenozóicos no Es- tado de São Paulo. IPT, São Paulo, 74 p.

Meyer, R. (1.987) Paléoaltérites et Paléosols: l'empreinte du continent dans les séries sédimentaires. BRGM, Orleans, 163p.

Milne, G. (1935) Some suggested units of classification and mapping particularly for East African soils. Soil Research. 4(3).

Morrison, R. B. (1967) Principles of Quaternary stratigraphy. In Morrison, R. B. e Wright, H. E. (ed) Quaternary Soils. Proceedings of the $7^{\text {th }}$ Congress of the International Association of Quaternary Research. Vol. 9, 1-69.

Nahon, D.; Lappartient, J-R. (1977) Time factor and geochemistry in iron crusts genesis. Catena. 4 (3): 249-254.

Penteado, M. M. (1968) Implicações tectônicas na gênese das cuestas da Bacia de Rio Claro. Notícia Geomorfológica, 8 (15):19-41.

Pires, F. R. M. (1982) Formação Bauru: controvérsias. An. Acad. Brasil. Ciênc., 54 (2): 369-393.

Platt, N.H.; Beatkeller (1992) Distal alluvial deposits in a foreland basin setting - the Lower Freshwater Molasse (Lower Miocene), Switzerland: sedimentology, architecture and paleosols. Sedimentology. 39: 545-565.

Ranzani, G.; Penteado, M. M.; Silveira A J. D. (1972) Concreções ferruginosas, paleossolo e a superfície de cimeira no Planalto Ocidental Paulista. Geomorfologia, $\mathrm{n}^{\mathbf{0}}$ 31, Instituto de Geografia/USP, $28 \mathrm{p}$.

Reading, H. G. (1986) Sedimentary Environments and Facies. Elsevier, New York, 615 p.

Retallack, G. J. (1990) Soils of the Past - An introdution to paleopedology. Unwin Hyman, London. 520p.

Retallack, G. J. (1997) A Colour Guide to Paleosols. Wiley. Chichester, England. 175 p.

Retallack, G.; McDowell, P. (1988) Paleoenvi-ronmental interpretation of paleosols. Geology, 375-376.

Riccomini, C. (1995) Tectonismo Gerador e Deformador dos Depósitos Sedimentares Pós-Gondvânicos da Porção Centro-Oriental do Estado de São Paulo e Áreas Vizinhas. Tese de Livre-Docência USP/ São Paulo (mímeo), 100 p.

Riccomini, C. (1997) Considerações sobre a posição estratigráfica e tectonismo deformador da Formação Itaqueri na porção centro-leste do Estado de São Paulo. Rev. I.G., 18 (1/2): 41-48.

Semmel,A. (1989) Paleopedology and geomorphology: examples from the Western part of Central Europe. Bronger, A.; Catt, J.A. (ed) Paleopedology: Nature and application of paleosols. Catena Supplement, 16. p.143-162.

Simon-Coinçon, R. Palaeolandscape reconstruction of the south-western Massif Central (France). Thiry, M.; 
Simon-Ccoinçon, R. (ed) Palaeoweathering, Palaeosurfaces and Related Continental Deposits. IAS/Blackwell Science. 225-244, 1999.

Soares, P. C. (1974) Elementos estruturais da parte nordeste da Bacia do Paraná: classificação e gênese. In: Congresso Brasileiro de Geologia, 28., Porto Alegre, Anais... Porto Alegre: SBG, v. 4, p. 107-121.

-Soares, P. C.\& Landim, P. M. B. (1976) Depósitos cenozóicos na região centro sul do Brasil. Notícia Geomorfológica, 16 (31): 17-39.

Summerfield, M.A. (1991) - Global Geomorphology. Longman Scientific \& Technical, New York, 537p.

Tardy, Y. (1993) Petrologie des Laterites et des Sols Tropicaux. Paris, France, Masson, 461 p.

Thiry, M. (1999) Diversity of continental silicification features: examples from the Cenozoic deposits in the Paris Basin and neighbouring basement. Thiry, M.; Simon-Coinçon, R. (ed) Palaeoweathering, Palaeosurfaces and Related Continental Deposits. IAS/Blackwell Science. 87-128.
Thiry, M.; J.-M. Schimitt; Simon-Coinçon, R. (1999) Problems, progress and future research concerning palaeoweathering and palaeosurfaces. Thiry, M.; Simon-Coinçon, R. (ed) Palaeoweathering, Palaeosurfaces and Related Continental Deposits. IAS/Blackwell Science. 3-20.

Twidale, C.R.; Bourne, J.A.. (1988) The use of duricrusts and topographic relationships in geomorphological correlation: conclusions based in Australian experience. Catena, 33: 105-122.

Twidale, C.R.; Bourne, J.A.; Smith, D.M. (1976) Age and origin of paleosurfaces on Eyre Peninsula and the southern Gawler Ranges, South Australia. Z. Geomorph. N.F., 20 (1):28-55.

Wright, V. P. (1992) Paleopedology: strtigraphic relationship and empirical models. In Martini, I. P. e Chesworth, W. (ed.) Weathering, Soils e Paleosols. Elsevier, Amsterdan, Holand. 475-499p 